\author{
Aurelija Daukšaitè \\ Vytautas Magnus University, Lithuania
}

\title{
NEGATIVE TRANSFER IN LITHUANIAN STUDENTS' WRITING IN ENGLISH
}

Summary. This research intends to find out whether Lithuanians studying English as a foreign language make certain mistakes because of the influence of their native language. It focuses on negative transfer in writing in English and is qualitative rather than quantitative. The article discusses the errors and illustrates them with examples that come from a corpus for which the data was obtained from 34 Moodle forum posts written by English B2 students, native speakers of Lithuanian who were in year one or year two of their studies in various study programmes but also studied English at Vytautas Magnus University as an obligatory subject. The students participated in this forum in October 2018 and reflected on the week of presentations they had recently had: they were asked to write what they liked or did not like in the presentations their colleagues had given in class, what went well and what did not, what they should improve in the future, etc. This study identified the types of errors (based on Camilleri, 2004) that occurred most frequently and their source (based on Camilleri, 2004; Brogan \& Son, 2015). Most frequently the students made errors in the cases where there was a specific grammatical category in English, but it was non-existent in Lithuanian, while sometimes the source of errors was literal translation from the native language. The error analysis shows that in the English classroom specific attention should be given to the verb forms "is" and "are", "was" and "were", "has" and "have", articles, collocations, tense agreement, quantifiers, the sentence structure of the English language and the importance of word meanings.

Keywords. EFL; TEFL; negative transfer; Lithuanian students; VMU.

\section{Introduction}

In scientific publications by Lithuanian researchers, whose research deals with the Lithuanian language, English is mostly seen as the language that damages or even ruins the Lithuanian language, which is archaic and therefore must be protected. For instance, Rudaitienè (2011, p. 40) focuses on English as having an effect on the lexis of the Lithuanian language and the use of loanwords, for English is considered to be one of the most important factors of globalisation. According to Rudaitienè's research (2011), models of the English language are transferred into Lithuanian, not vice versa. In her other research, Rudaitienè (2014, p. 119) claims that the Lithuanian semantics is adapted to the English semantics, which, according to her, again shows a negative impact of English on the Lithuanian language. In addition, in her article, Kamandulytè- 
Merfeldienè (2018) discusses the influence of foreign languages, especially English, on the Lithuanian lexis and the use of loanwords in the discourse of scientific publications, administrative language and other discourses. Odlin (2003) refers to this phenomenon of influence as "borrowing transfer" which can be described as "the influence a second language has on a previously acquired language (which is typically one's native language)" (p. 12). However, the research by Kamandulytè-Merfeldienè suggests that even though it is claimed that English has a great impact on the Lithuanian language and its use, in fact only 0.33 per cent of vocabulary in Lithuanian is borrowed from other languages (the majority, 93 per cent, is from English) (KamandulytèMerfeldienè, 2018, p.14). In other words, there is not as much negative impact on the Lithuanian language by the English language as it is thought. This obviously has to do with the fact that the native language is learned first and only later, when foreign languages are studied, some aspects are transferred to the use of the native language.

At present, many scholars research the opposite phenomenon the influence of one's native language, such as Arabic (Sabbah, 2015), Indonesian (Wahyuni \& Sudarsono, 2017), Chinese (Shi, 2015), Spanish (Calvo Cortes, 2005; Arrufat Mingorance, 2010), Turkish (Mede, Tutal, Ayaz, \& Akin, 2014) or Vietnamese (Cong Ngoc, 2016; Van Vu, 2017), on the second or foreign language, which is often English, learning. Sparks and Ganschow (1993) review various case studies and suggest that "there might be a native language basis for FL learning problems" (Sparks \& Ganschow, 1993, p. 59). Moreover, Shin et al. (2015, p. 257) state that "there seems to be a lack of empirical research demonstrating the role of $L 1$ writing on $L 2$ reading and/ or writing, because reading and writing are inextricably bound together as two major components of literacy." Dich and Pedersen (2013, p. 51), meanwhile, explore "first language (L1) influences on the mechanisms of spelling in English as a foreign language (EFL)". The participants of their research were adults whose native languages were Danish, Russian and Italian, and there was a group of native speakers of English that they compared the research results of non-native speakers with. Dich and Pedersen (2013, p. 60) conclude that "cross-linguistic differences result from spellers' transfer of their L1 spelling strategies: i.e. native language characteristics influence the ways spellers parse words when they type in L1, and when they learn 
to spell in English as an L2, they group the symbols the same way they do in their native language." That is, one's native language interferes with foreign language learning. According to Odlin, the "term interference implies no more than what another term, negative transfer, does, but there is an advantage in using the latter term since it can be contrasted with positive transfer, which is the facilitating influence of cognate vocabulary or any other similarities between the native and target languages" (Odlin, 2003, p. 26, italics in original). This means, that one's native language has both positive and/or negative effect on foreign language learning.

\section{Negative Transfer in Foreign Language Classes}

In general, it is believed that similarities between L1 and L2 may lead to positive language transfer, while differences might be related to negative transfer in a foreign language classroom (Darginavičienè \& Navickienè, 2015, p. 110). Usually positive transfer occurs if L1 and L2 share the following linguistic features:

1) An alphabetical system;

2) Particular grammatical categories;

3) Rhetorical conventions (Camilleri, 2004, p. 4).

In addition, it can also be reflected in reading or speaking strategies or the use of metalanguage (Camilleri, 2004, p. 4). While learning a foreign language, "the influence arises from a learner's conscious or unconscious judgement that something in the native language (most typically) and something in the target language are similar, if not actually the same", but "the conditions that trigger judgements of similarity or identity remain incompletely understood" (Odlin, 2003, p. 27-28). However, negative transfer takes place if/ when/ "where there is a 'mismatch' between [...] an L1 structure and the equivalent target structure" (Camilleri, 2004, p. 5). It is often referred to as "interference," "cross-meaning" (Brogan \& Son, 2015: 48), "a negative transfer error," and "mother tongue interference" (Camilleri, 2004, p. 5). Other terms related to $L 1$ could also be used. For instance, negative transfer errors from 
the Maltese language are called "Malteisms" or negative transfer errors from Lithuanian are referred to as "Lithuanianisms".

In his research, Camilleri (2004, p. 6) identified thirteen types of errors of negative transfer: noun, adjective, adverb, verb, verb form, preposition, article, spelling, idiom, pronoun, passive voice, word order, and concord, but the most frequent were those of preposition, verb and idiom. In the research by Camilleri, the sources of errors included the following: literal translation, differentiation, coalescing, L1 form, false friend, and a new category (Camilleri, 2004 , p. 8). It is expected that the research described in this paper will probably deal with a high number of negative transfer errors related to literal translation and the so-called new category, so it is useful to look at how they are defined. As Camilleri describes, literal translation "refers to errors caused by a process of direct translation, whether they be single words [...] or an entire string of words," while a new category "refers to the existence of a grammatical category in English which is not found" in L1 (Camilleri, 2004, p. 8). For example, there are no articles in Lithuanian, so it is a source for possible errors. The research results will show whether the hypothesis on the sources of the most common negative transfer errors in Lithuanian students' writing in English can be confirmed. It is also important to emphasise that there is no single classification of such errors, so different researchers use different terms to refer to them and the number of identified categories may differ greatly. In comparison to Cimilleri's classification, Brogan and Son divided the sources of errors of their research into the following three groups:

1) Overextention of analogy. These errors occur "when the learner misuses an item or form in the L2; this can occur on the phonological, lexical, or orthographic level."

2) Transfer of structure. It "occurs when the learner utilizes a feature of the L1 instead of that of the target language."

3) Interlingual/ intralingual errors. They "occur when there is a particular distinction in one language but not in the other" (Brogan \& Son, 2015 , p. 51). The previously given example of a lack of articles in Lithuanian would probably fall under this category of errors. 
The research by Brogan and Son (2015) at the University of California, the USA, shows that "transfer errors do not become less relevant as student proficiency increases, [but] the most frequent types change from level to level" (p. 47). In other words, the issue of negative transfer is common in all levels of foreign language learning.

\section{Research Aim, Methodology, Participants, and Limitations}

The present research deals with the way Lithuanian, as a native language, influences the learning process of English when Lithuanians study English. As Lithuanian and English are very different languages, belonging to separate language families, the study intends to find out whether Lithuanians studying English as a foreign language make certain mistakes because of the influence of their native language. The terms "mistake" and "error" are not differentiated here, because it is not known if the research participants would be able to identify and correct them or not. In addition, other scholars who carry out research on negative transfer use both terms as well.

The focus of the present research is negative transfer in writing and is qualitative rather than quantitative. It will discuss the errors made by Lithuanian students at VMU and illustrate them with examples. The examples come from a corpus of 24,450 words. The data was obtained from 34 forum posts in the Moodle virtual learning environment written by English B2 students, native speakers of Lithuanian who were in year one or year two of their studies in various fields but also studied English at university level as an obligatory subject in their study programmes. In fact, there were 41 posts, but seven, written by non-Lithuanian students, were taken out of the corpus. The students participated in this forum activity in the virtual learning environment on October 22-26, 2018. In this forum, they reflected on the week of presentations they had had: the students were asked to write what they liked or did not like in the presentations their colleagues had given in class, what went well and what did not, what they should improve in the future, etc.

The research aims at investigating to what extent negative transfer is common in Lithuanian students' writing in English and identifying the types of errors that occur most frequently. Odlin states that "[o]ne of the major 
challenges for error analysts is deciding what category to assign a particular error to. For example, omitting an article in English may quite arguably be a case of simplification with a Spanish speaker but a case of transfer with a Korean speaker" (Odlin, 2004, p. 19). That is, error and/ or error source analysis is a rather arbitrary process, but as a native speaker of Lithuanian, the author of the paper tried to identify and imply which of the errors might have been made because of the negative transfer from L1 (Lithuanian) and assign them to categories. This might be seen as a limitation of the research and its results, but the research itself does not aim at providing a complete list of negative transfer errors from Lithuanian. As Camilleri notes, under ideal circumstances the researcher should ask every research participant to explain why mistakes have been made, but they are sometimes unable to explain this, and the researcher does not always have a possibility to discuss the errors soon after they have occurred (Camilleri, 2004, p. 5). This was the case in this research. In other words, the main limitations of the research are a limited research scope and the fact the research participants were not asked to explain why they had made the mistakes that were later analysed.

\section{Results and Discussion}

The research findings indicate that the negative transfer was in operation in the Moodle posts that were analysed but less prevalent than expected before the research. This could be due to the fact that the forum posts by English B2 students were analysed rather than those of lower levels, for lower level students are thought to use negative transfer more frequently. However, this should be tested and could be seen as a recommendation for further research in the future. In fact, the research by Brogan and Son (2015) intentionally chose to include young adults, non-native speakers of English of elementary level, in order to obtain more negative transfer errors for their analysis (p. 49).

\section{Use of Articles}

As expected, the use of articles caused many problems to Lithuanian students of English B2. Since there are no articles in the Lithuanian language, naturally, 
Lithuanian students of English tend not to use articles at all or use them incorrectly. Most frequently the definitive article "the" was not used at all where it should have been used. The gaps in the examples show where the definite article was missing. The students wrote about specific topics/ presentations/ slides, etc., so this article should have been in frequent use but was omitted instead.

Table 1.

\section{Omission of the Definite Article}

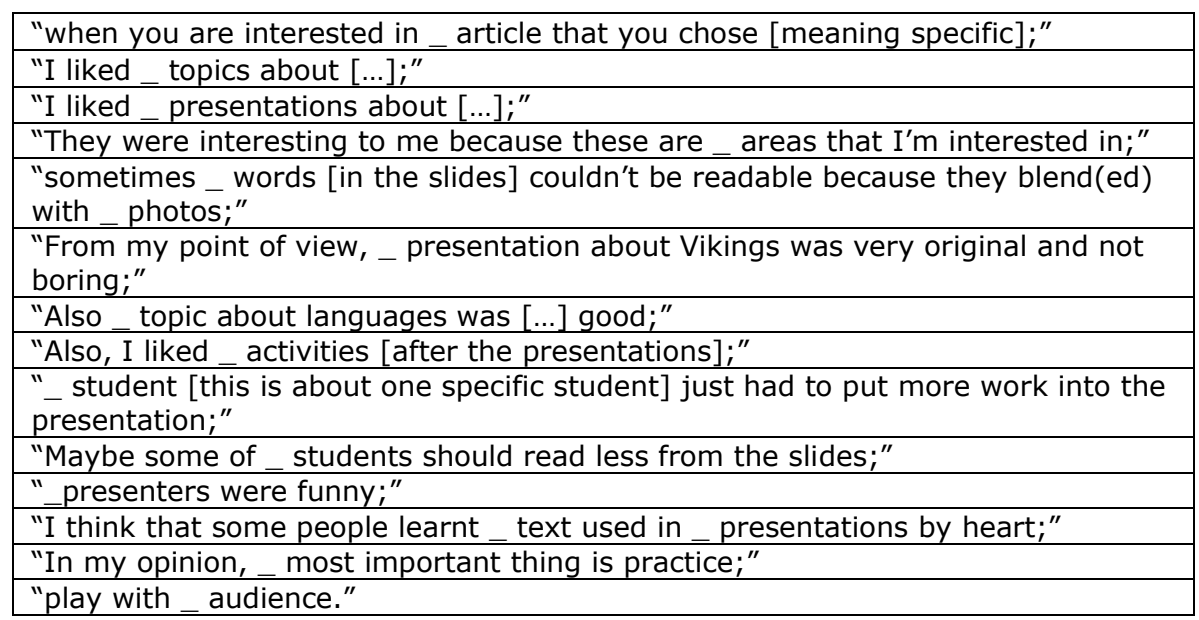

There were some cases when the indefinite article was omitted, but this did not happen as often as in the case of the definite article. The gaps in the examples show where the indefinite articles were missing.

Table 2.

\section{Omission of the Indefinite Article}

"In my opinion, _ successful presentation is when [...]";

"I think for _ presentation to be successful you need [...]";

"Each student was original in _ specific way";

"The best tip to _ person who is going to talk." 
Having analysed the errors in the corpus of the research, it is possible to state that the use of the indefinite article instead of the definite one was not common either, for there were only several cases of such usage: "I frankly enjoyed a (the) presentation about [...]" and "to talk in front of an (the) audience [...]" (there were other three similar examples). According to Cammileri's classification, the type of error here was "article", while the source was the socalled "new category". As discussed, Brogan and Son refer to such errors as "interlingual/ intralingual errors."

\section{Use of Prepositions}

Preposition errors usually were observed in the situations where there was no preposition used in the Lithuanian language but should have been used in English, e.g. "I am not afraid to talk [...] in Lithuanian" (It. Man nebaisu kalbèti _ lietuviškai) and "it is a little bit hard to do it in English" (It. šiek tiek sunku tą daryti _ angliškai). Although prepositions as such exist in Lithuanian, they are not necessarily always used in the same situations as in English. The examples of errors provided here were probably caused by the form of L1 that had no preposition (overextention of analogy). Nevertheless, preposition errors were not frequent in the Moodle posts that were analysed.

\section{Verb Forms}

The error of verb form was not expected to be so frequent in the Moodle posts of English B2 students. The confusion of "is" vs. "are," "was" vs. "were" and "have" vs. "has" would probably be associated to lower levels of English, but in Lithuanian, both "is" and "are" mean "yra," and the same verb is used with singular and plural nouns. Even though "is" and "are" were not confused as often as "was" and "were", some cases were noticed. For instance, "there is (are) a lot of things." "Was" and "were" both are translated into Lithuanian as "buvo" which is used with both singular and plural nouns. This is the reason why some Lithuanian students forget it is not the same in English. 


\section{"Was" / "were" confusion}

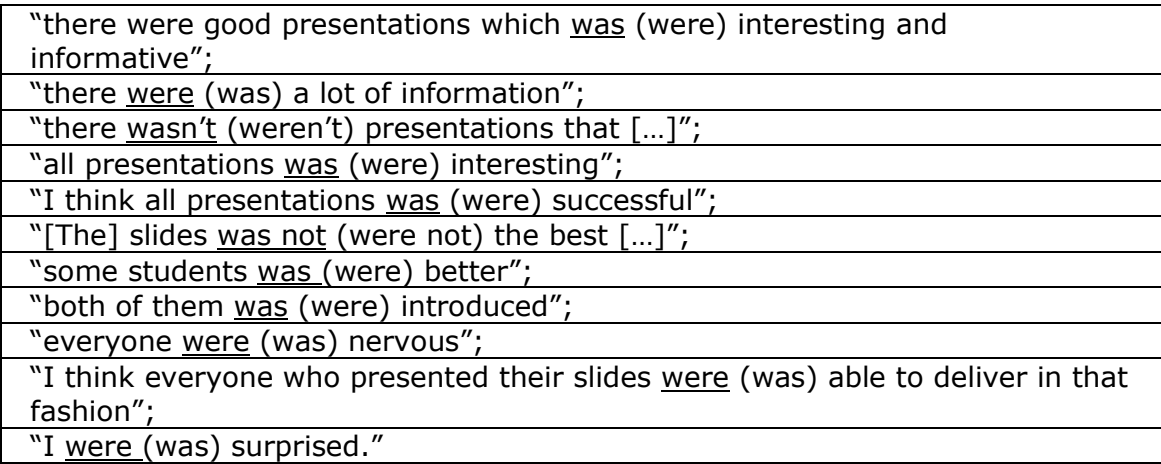

A similar situation can be observed in the use of "have" and "has," for in Lithuanian, both of them mean "turi," and this verb is used with both singular and plural nouns. This is the reason that sometimes the confusion of "have" and "has" leads to mistakes in Lithuanian students' writing in English. For example, "It have (has) to be"; "First of all, the information have (has) to be clear"; "The presenter have (has) to look confident." The source of these errors cannot be easily identified, since there is no clear tendency for them to appear under any specific circumstances. However, as there is a grammatical distinction of these three categories (is/ are, was/ were and has/ have) in English but there is none in Lithuanian, this type of errors once again could be assigned to interlingual/ intralingual errors and/ or the so-called new category.

Another group of verb form errors was related to tense agreement. In Lithuanian, there is no rule on tense agreement, but in English, present tenses go together with other present tenses or future tenses, while past tenses are used with other past tenses. As observed in the corpus or this research, Lithuanian students of English B2 tended to use tenses in English in the same way they would in Lithuanian. 


\section{Tense Agreement}

\begin{tabular}{|l|}
\hline "we all [...] do what we are told; after all, we were (are) thought to be like that \\
everywhere"; \\
\hline "it was a little bit hard to understand what the presenters want(ed) to say"; \\
\hline "there was a huge difference between those people who talk (talked) about \\
(the) topic they really enjoy(ed) to talk about than those who talk(ed) [...]"; \\
\hline "Some students were using difficult words or sometimes I thought that they do \\
(did) not know what they are (were) talking about"; \\
\hline "Others chose difficults words which they do (did) not know and it made their \\
presentation more difficult to understand."
\end{tabular}

The last example is especially interesting, because the student applied the Lithuanian grammar rule which states that adjectives have to agree with nouns in gender, number and case. In the phrase "difficults words," the adjective "difficult" is made plural in order to agree with the plural noun "words" by adding the suffix "-s". This error can be assigned to the type of adjective errors and can be seen as an overextention of analogy. It is definitely caused by the L1 form "sunkūs žodžiai," in which both the adjective and the noun are plural. No other similar cases were present in the corpus of the research, so adjective errors will not be discussed separately in this article.

The last group of verb errors can be seen in the use of collocations with "do" and "make." Both verbs mean "daryti" in Lithuanian and there is no difference in meaning. As a result, the Lithuanian students of English B2 found it difficult to choose correctly in the following examples: "all students do (It. daro) great presentations" -> make (It. daro); "to do (It. daryti) the slide" -> to make (It. daryti); "you did (It. padarei) some sort of mistake" -> made (It. padarei). It appears that the verb "do" was used where "make" had to be used, not vice versa. It is difficult to decide why this happened, but it is possible to assume that in terms of the meaning of the verb "daryti," "do" would come to one's mind first and even the first letter of the verb is the same. 


\section{Use of Pronouns}

In Lithuanian, it is possible to have a sentence without an overt subject. This becomes a problem for Lithuanian students while studying English, which is often referred to as the so-called SVO language and requires that the subject is used. In the present research, impersonal constructions seemed to be the most problematic, for "it" was omitted in English sentences, since the equivalent of "it," or anything else for that matter, would not have been used in Lithuanian. The examples are as follows: "- (It) is important to communicate with the audience" and "I know how difficult _ is to stand up in front of the audience and try not to mess up." There were other constructions in which the pronoun was missing but the constructions where personal rather than impersonal. An example could be the following: "Also, _ need to fight (with) our fear". "I" or "we" could be suitable in this context. In Lithuanian, the verb suffix would reveal the pronoun, but in English it does not. The pronoun errors discussed here belong to the group of interlingual/ intralingual errors (Brogan and Son's classification) and are related to either the so-called new category or literal translation (Camilleri's classification).

\section{Use of Quantifiers}

This type of errors is not identified by Camilleri (2004) but was noticed in the analysis of errors in this research. In fact, only the confusion of "much" vs. "many" was noticed in the Moodle posts written by Lithuanian students of English B2. In Lithuanian, both "much" and "many mean "daug." "Daug" is used with both singular and plural nouns. Therefore, Lithuanian students who study English may not always think about the fact that different quantifiers are used in English: "many (much) information" or "not too much (many) [slides]." Just like other errors that have been discussed so far, this one is caused by a new category that exists in L2 but not in L1.

There were other miscellaneous errors, too. They are grouped by Camilleri into noun, adjective, adverb, and verb errors, but his classification is not very useful in this research, for there were only a few cases of each error. However, what unites these errors is the fact that all of them are related to 
the students' choice of vocabulary relying on L1. The students most frequently used literal translation when choosing to use a word similar in terms of spelling of the word or meaning in L1.

In fact, there may have been more errors, not related to negative transfer from L1. For example, there were numerous spelling errors but all of them were probably typing errors. In order to compare the negative transfer errors with non-negative transfer errors, their ratio should also be counted. Nevertheless, the research did not have such an aim. This could be one more recommendation for further and in-depth research.

\section{Conclusion}

A larger scope would have made the research findings more significant and informative, but even now it provides a valuable insight into negative transfer in Lithuanian students' writing in English.

It is useful to study students' errors, for this might help English teachers to plan teaching materials and lectures in order to avoid them. As the discussion on the research results reveals, most frequently Lithuanian students studying general English at B2 level at VMU made errors in the cases where there was a specific grammatical category in English but it was non-existent in Lithuanian, while the main sources of errors were related to literal translation from the native language or a category that does not exist in L1 (Lithuanian).

The error analysis shows particular areas that should be given specific attention in the English classroom, such as the verb forms "is" and "are", "was" and "were", "has" and "have", articles, collocations, tense agreement, quantifiers, the sentence structure of the English language and the importance of multiple word meanings, so such words should be chosen carefully. Many of the mentioned language issues are usually introduced and taught at lower level English classes than B2, therefore, it is possible to assume that the teachers and/or the students did not dedicate proper time and effort to them at that time and the errors continued to be made in higher levels, such as B2. This is why it would be a good idea to emphasise the differences between English and Lithuanian in the English classroom, which might help to avoid negative transfer. 
It is hoped that this research will encourage English teachers of all levels who teach Lithuanian students to spend more time on and pay the students' attention to the discussed problematic areas that probably can be observed not only in the writing of Lithuanian students but also in speaking.

\section{References}

Arrufat Mingorance, Y. (2010). How to Deal with Language Transfer in the English Classroom (pp. 1-7). Retrieved from http://www.eduinnova.es/mar2010/how_to_deal.pdf.

Brogan, F. D., \& Son, J. (2015). Native Language Transfer in Target Language Usage: An Exploratory Case Study. Voices, 3(1), 47-62. Retrieved from https://escholarship.org/content/qt7cd3n9xh/qt7cd3n9xh.pdf.

Calvo Cortes, N. (2005). Negative Language Transfer When Learning Spanish as a Foreign Language. Interlinguistica, 16(1), 237-248. Retrieved from https://dialnet.unirioja.es/descarga/ articulo/2514223.pdf.

Camilleri, G. (2004). Negative Transfer in Maltese Students' Writing in English. Journal of Maltese Education Research, 2(1), 3-12. Retrieved from http://www.mreronline.org/wpcontent/uploads/2013/07/JMERN2I1P11.pdf.

Cong Ngoc, P. (2016). Negative Mother Tongue Language Transfer into English Writing Learning of First Year Advanced Program Students at Vietnam National University of Forestry. Journal of Forest Science and Technology, 3, 183-192. Retrieved from http://vnuf.edu.vn/documents/454250/1807810/21.pdf.

Darginavičienè, I., \& Navickienè, V. (2015). Use of Native Language in Learning English for Specific Purposes. Tiltai, 2, 109-123. Retrieved from http://journals.ku.It/index.php/tiltai/article/viewFile/1104/pdf.

Dich, N., \& Pedersen, R. (2013). Native Language Effects on Spelling in English as a Foreign Language: A Time-Course Analysis. The Canadian Journal of Applied Linguistics, 16(1), 51-68. Retrieved from https://files.eric.ed.gov/fulltext/EJ1005020.pdf.

Kamandulytè-Merfeldienè, L. (2018). Svetimu kalbu intarpai sakytinèje lietuviu kalboje. Lietuvic kalba, 12, 1-18. Retrieved from 
http://www.lietuviukalba.It/index.php/lietuviu-

kalba/article/viewFile/248/187.

Mede, E., Tutal, C., Ayaz, D. \& Akin, S. (2014). The Effects of Language Transfer in Turkish EFL Learners. ELT Research Journal, 3(2), 70-83. Retrieved from http://dergipark.gov.tr/download/article-file/63638

Odlin, T. (2003). Language Transfer: Cross-Linguistic Influence in Language Learning (6th ed.). Cambridge: Cambridge University Press.

Rudaitienè, V. (2011). Lietuviu kalba ir sociokultūriniai veiksniai. Žmogus ir žodis, 3, 40-49. Retrieved from http://www.biblioteka.vpu.It/zmogusirzodis/PDF/svetimosioskalbos/2 011/rud40-49.pdf.

Rudaitienè, V. (2014). Kalbu kontaktai ir lietuviu kalbos tradicija. Žmogus ir žodis, 16(3), 111-121. Retrieved from http://www.zmogusirzodis.leu.It/index.php/zmogusirzodis/article/vie $\mathrm{w} / 88 / 85$.

Sabbah, S. S. (2015). Negative Transfer: Arabic Language Interference to Learning English. Arab World English Journal, Special Issue 4, 269288.

Retrieved from http://awej.org/images/AllIssues/Specialissues/Translation4/17.pdf.

Shi, W. (2015). Types of Chinese Negative Transfer to English Learning and the Countermeasures. Theory and Practice in Language Studies, 5(6), 1226-1232. Retrieved from http://www.academypublication.com/ojs/index.php/tpls/article/view/t pls050612261232/252.

Shin, J., Sailors, M., McClung, N., Pearson, P.D., Hoffman, J.V. \& Chilimanjira, M. (2015). The Case of Chichewa and English in Malawi: The Impact of First Language Reading and Writing on Learning English as a Second Language. Bilingual Research Journal, 38, 255-274. Retrieved from https://www.researchgate.net/publication/286930818_The_Case_of_ Chichewa_and_English_in_Malawi_The_Impact_of_First_Language_R eading_and_Writing_on_Learning_English_as_a_Second_Language.

Sparks, R. L. \& Ganschow, L. (1993). The Impact of Native Language Learning Problems on Foreign Language Learning: Case Study Illustrations on 
the Linguistic coding Deficit Hypothesis. The Modern Language Journal, 77(1), 58-74. Retrieved from https://www.jstor.org/stable/329559.

Van Vu, D. (2017). An Empirical Study on Negative Transfer in Vietnamese Tertiary EFL Learners' English Writing. The Journal of Teaching English for Specific and Academic Purposes, 5(4), 661-668. Retrieved from http://espeap.junis.ni.ac.rs/index.php/espeap/article/view/594/360

Wahyuni, S.S. \& Sudarsono, Z.A. (2017). Analysis of Negative Transfer of "Indonesian" as "SL" Into "English" as "FL". Jurnal Pendidikan dan Pembelajaran, 6(9), 1-9. Retrieved from http://jurnal.untan.ac.id/index.php/jpdpb/article/view/21637. 


\section{Aurelija Daukšaitè}

Vytauto Didžiojo universitetas, Lietuva; aurelija.dauksaite@vdu.It

\section{NEIGIAMAS PERKĖLIMAS LIETUVIU STUDENTAMS RAŠANT ANGLIŠKAI}

Santrauka. Šiuo tyrimu siekiama sužinoti, ar lietuviai, besimokantys anglu, kaip užsienio, kalbos daro klaidu dèl savo gimtosios kalbos itakos. Straipsnyje tiriamas neigiamas perkèlimas iš lietuviu kalbos rašant angliškai, o pats tyrimas yra labiau kokybinis negu kiekybinis. Jame aptariamos klaidos, kurios iliustruojamos pavyzdžiais iš 34 forumu žinučiu, kurias 2018 m. spali parašè anglu kalbos B2 lygiu besimokantys pirmo arba antro kurso Vytauto Didžiojo universiteto studentai. Žinutėse jie reiškè savo nuomonę ir teikè grižtamaji ryši apie praejjusią pristatymu savaitę anglu kalbos paskaitose: buvo rašoma, kas (ne)patiko kitu studentu pristatymuose, kas (ne)gerai pavyko, ka reikètu patobulinti ateityje ir kita. Remiantis Camilleri (2004), dažniausiai pasitaikiusios neigiamo perkélimo klaidos buvo suskirstytos i tipus; taip pat bandyta nustatyti tokiu klaidu šaltinius (remiantis Camilleri, 2004; Brogan ir Son, 2015). Dauguma studentu rašydami angliškai dare klaidu ten, kur lietuviu kalboje tam tikra gramatinè kategorija nèra išskiriama, bet ji egzistuoja anglu kalboje, o kartais neigiamo perkèlimo klaidas itakojo tiesioginis ar pažodinis vertimas iš lietuviu kalbos i anglu kalba. Klaidu analizè parodè, kad anglu kalbos paskaitose didesnis dèmesys turètu būti skiriamas veiksmažodžio formoms "is" ir "are", "was" ir "were", "has" ir "have", artikeliams, kolokacijoms, laiku derinimui, kiekybiniams ivardžiams, anglu kalbos sakiniu struktūrai ir anglišku žodžiu daugiareikšmiškumui.

Pagrindinès sąvokos: anglu kalbos mokymas(is); neigiamas perkèlimas; lietuviai studentai; rašymas angliškai; VDU. 